\title{
Taxonomic study of the genus Achnanthes (Bacillariophyta) in Korean coastal waters
}

\author{
Sang Deuk Lee, Joon Sang Park and Jin Hwan Lee* \\ Department of Life Science, Sangmyung University, Seoul 110-743, Korea
}

\begin{abstract}
A study on the fine structure of the genus Achnanthes species (Bacillariophyceae) is carried out at 92 stations for taxonomic purposes from January 2009 to April 2013 in Korean marine water, freshwater and brackish water. Twelve Achnanthes species are identified based on a variety of taxonomic characters by means of light microscopy and scanning electron microscopy. Of these, seven species, Achnanthes cocconeioides, A. groenlandica, A. javanica, A. kuwaitensis, A. parvula, A. pseudolongipes, and A. yaquinensis, are newly recorded in Korean waters. All 12 species are documented concerning a taxonomic key, description, distribution, seasonality, remarks and photographs. Twenty three Achnanthes taxa are identified in the survey.
\end{abstract}

Key words: Achnanthes, Bacillariophyceae, diatoms, new to Korea

\section{INTRODUCTION}

The genus Achnanthes Bory comprises a group of monoraphid heterovalvar diatoms with Achnanthes adnata as the type species (Bory 1822). More than 500 species have been described in the genus Achnanthes in marine, fresh- and brackish waters (VanLandingham 1967). Recent studies on the monoraphid diatom have subdivided into new genera that include Achnanthidium Kützing (Round et al. 1990), Psammothidium Bukhtiyarova \& Round, Karayevia Round \& Bukhtiyarova ex Round, Kolbesia Round \& Bukhtiyarova ex Round, Rossithidium Round \& Bukhtiyarova (Round and Bukhtiyarova 1996) and Pogoneis Round \& Basson (Round and Basson 1997).

Toyoda et al. (2006) pointed out that there is no taxonomic information of the type and revised the type of the genus as Achnanthes brevipes Agardh through the examination of the lectotypus of Bory. The definition of Achnanthes sensu stricto has been revisited, and there are now probably fewer than 100 species and infraspecific taxa in the genus (Toyoda et al. 2006). Achnanthes sensu stricto differs from other achnanthoid diatoms in areolae, raphe, girdle and palstid structure (Round et al. 1990). The presence of cribrate areolae on both the valves and copulae is one of the most important features for discriminating between Achnanthes sensu stricto and other achnanthoid species (Toyoda et al. 2005a). Living material of Achnanthes species, with two or many peripheral chloroplasts, contrasts with other achnanthoid genera, which usually contain a single chloroplast (Toyoda et al. 2005b).

Thirty six taxa of Achnanthes species have been identified in Korea from the early 1930's to the mid-1990's (Lee 1995, Lee et al. 1995). Of these, only 14 species are the current valid name, 18 taxa of listed species are transferred into the other genera, two species are changed concerning the status or the author of the species, and two taxa are uncertain species name (Table 1). Although the number of Achnanthes species in Korea has been recorded, no http://dx.doi.org/10.5141/ecoenv.2013.391

(c) 5 This is an Open Access article distributed under the terms of
the Creative Commons Attribution Non-Commercial Licens
(http://creativecommons.org/licenses/by-nc/3.0/) which
permits unrestricted non-commercial use, distribution, and reproduction in any
medium, provided the original work is properly cited.
Received 29 October 2013, Accepted 19 November 2013

*Corresponding Author

E-mail: jhlee@smu.ac.kr Tel: +82-2-2287-5152 
taxonomic study has provided descriptions, illustrations or monographs, which has hampered the exact identification of the recorded species of Achnanthes sensu stricto. The aim of this study is to reveal the genus Achnanthes species focused on the fine structure during a survey conducted from January 2009 to April 2013 in marine, freshand brackish waters of Korea.

\section{MATERIALS AND METHODS}

Achnanthes species were collected at 92 stations in marine, fresh- and brackish waters of Korea from Jan 2009 to Apr 2013 (Appendix 1). Samples were collected by vertical or horizontal towing using a $20 \mu \mathrm{m}$ mesh-size plankton net. Net samples were immediately fixed with neutralized formalin (final concentration 4\%), glutaraldehyde (final concentration 2\%) or Lugol's solution (Sournia 1968). To examine the fine structure and taxonomic characteristics of the species, samples were cleaned of organic matter with concentrated $\mathrm{HCl}$ and saturated $\mathrm{KMnO}_{4}$ following the Hasle and Fryxell (1970)'s modified method. Permanent slides were made with the acid-cleaned materials, as follows. A drop of cleaned sample was put on a cover slip and dried using low heat. Pleurax mountant was put on each sample on a cover slip. The cover slip was put face-down on a slide glass and slightly heated using an alcohol lamp to evaporate the solvent. All specimens were observed using an Eclipse 80i light microscope equipped with bright-field and differential interference contrast optics (Nikon, Tokyo, Japan) with a DS-Fil digital camera (Nikon). Some cleaned specimens were individually dropped onto an aluminum stub and coated with goldpalladium. Coated samples were examined using a JSM5600LV scanning electron microscope (JEOL, Tokyo, Japan). Sizes of the diatom species were analyzed with Axio Vision AC v. 4.5 image calculation software (Carl Zeiss, Oberkochen, Germany). Terminology followed general proposals by Anonymous (1975), Ross et al. (1979) and Toyoda et al. (2003).

\section{RESULTS AND DISCUSSION}

Twelve Achnanthes species were identified in the present study. Taxonomic information of all species included synonym, description, morphometric data (Table 2), distribution, reference, seasonality, taxonomic remarks and illustrations about respective species.

Table 1. List of Achnanthes species in Korea

\begin{tabular}{|c|c|c|}
\hline Species name in previous study & Valid species name & Literature \\
\hline Achnanthes brevipes var. brevipes & Achnanthes brevipes var. brevipes & Lee et al. 1995; Lee 1995; This study \\
\hline Achnanthes brevipes var. intermedia & Achnanthes brevipes var. intermedia & Lee et al. 1995; this study \\
\hline Achnanthes clevei var. rostrata Hustedt & Achnanthes clevei var. rostrata Hustedt & Lee et al. 1995 \\
\hline Achnanthes coarctata & Achnanthes coarctata & Lee et al. 1995; this study \\
\hline Achnanthes cocconeioides & Achnanthes cocconeioides & This study \\
\hline Achnanthes convergens Kobayasi & Achnanthes convergensKobayasi & Lee et al. 1995 \\
\hline Achnanthes crenulata Grunow & Achnanthes crenulata Grunow & Lee et al. 1995 \\
\hline Achnanthes groelandica & Achnanthes groelandica & This study \\
\hline Achnanthes inflata (Kützing) Grunow & Achnanthes inflata (Kützing) Grunow & Lee et al. 1995 \\
\hline Achnanthes javanica & Achnanthes javanica & This study \\
\hline Achnanthes koreana Skvortzow & Achnanthes koreana Skvortzow & Lee et al. 1995 \\
\hline Achnanthes kuwaitensis & Achnanthes kuwaitensis & This study \\
\hline Achnanthes lapidosa var. lanceolata Hustedt & Achnanthes lapidosa var. lanceolata Hustedt & Lee et al. 1995 \\
\hline Achnanthes longipes & Achnanthes longipes & Lee et al. 1995; Lee 1995; This study \\
\hline Achnanthes marginulata Grunow & Achnanthes marginulata Grunow & Lee et al. 1995 \\
\hline Achnanthes parvula & Achnanthes parvula & This study \\
\hline Achnanthes pseudolongipes & Achnanthes pseudolongipes & This study \\
\hline Achnanthes subconstricta & Achnanthes subconstricta & Lee et al. 1995; Lee 1995; This study \\
\hline Achnanthes subhudsonis Hustedt & Achnanthes subhudsonis Hustedt & Lee et al. 1995; Lee 1995 \\
\hline $\begin{array}{l}\text { Achnanthes subhudsonis } \\
\text { var. kraeuselii (Cholnoky) Cholnoky }\end{array}$ & $\begin{array}{l}\text { Achnanthes subhudsonis } \\
\text { var. kraeuselii (Cholnoky) Cholnoky }\end{array}$ & Lee et al. 1995 \\
\hline Achnanthes temperi Peragallo & Achnanthes temperi M. Peragallo & Lee et al. 1995 \\
\hline Achnanthes trinodis (Ralfs) Grunow & Achnanthes trinodis (Ralfs) Grunow & Lee et al. 1995 \\
\hline Achnanthes yaquinensis & Achnanthes yaquinensis & This study \\
\hline
\end{tabular}




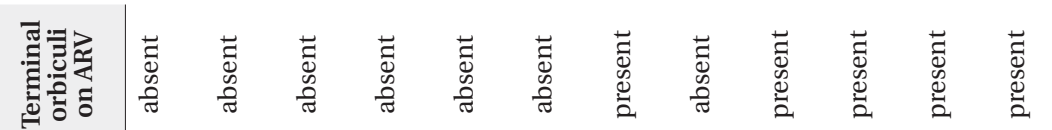

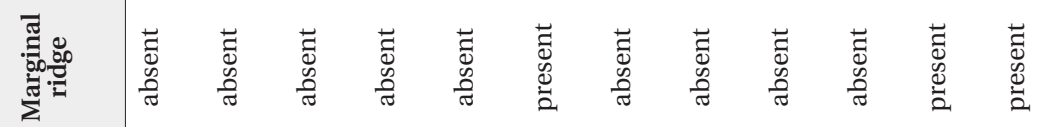

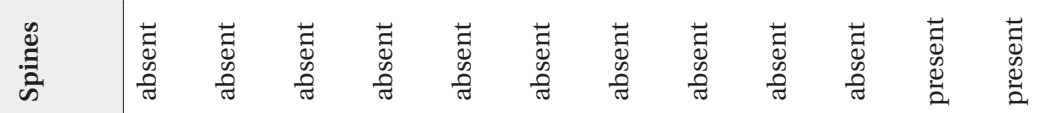

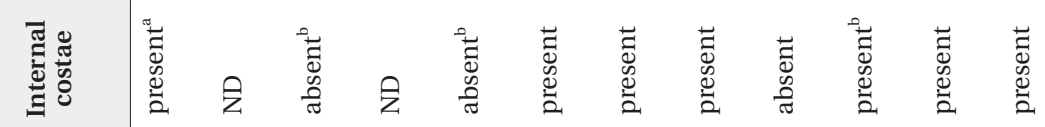

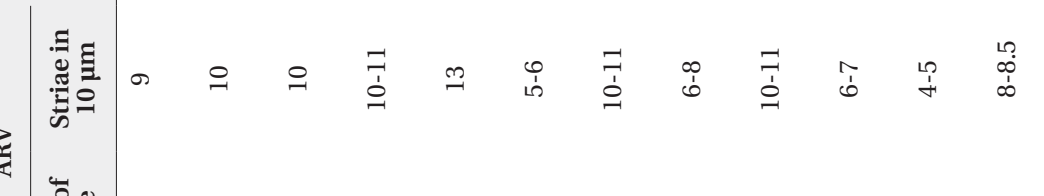

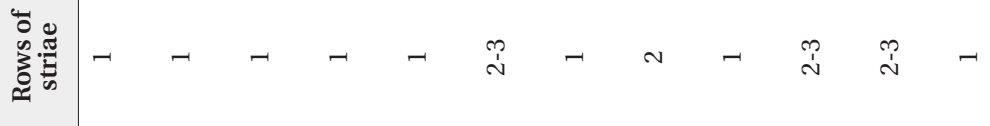

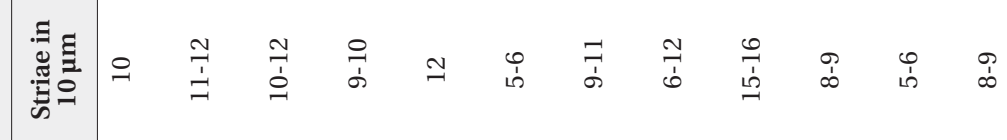
ฉ

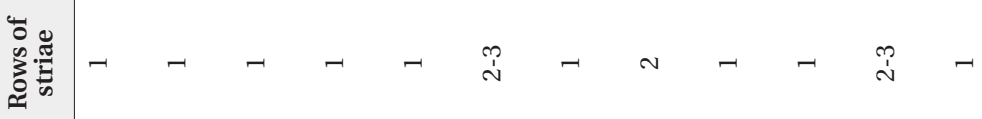

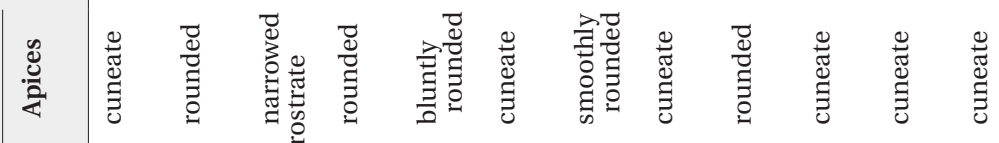

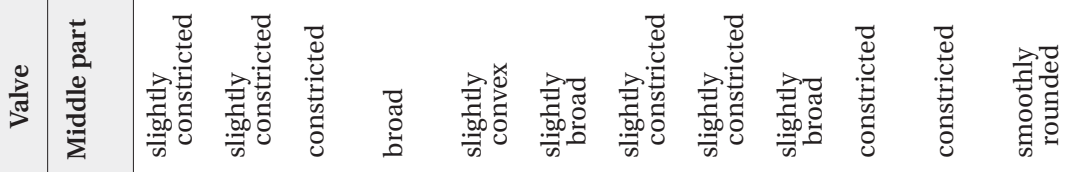

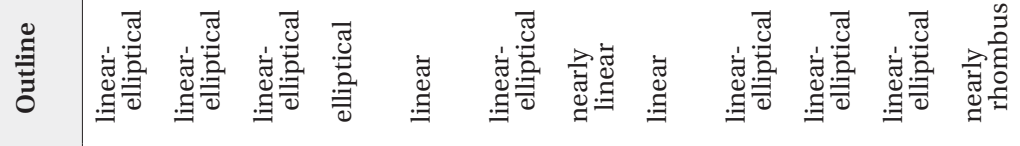

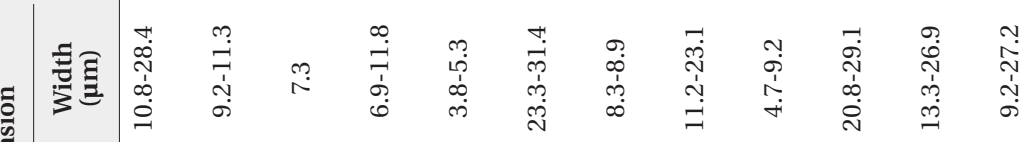

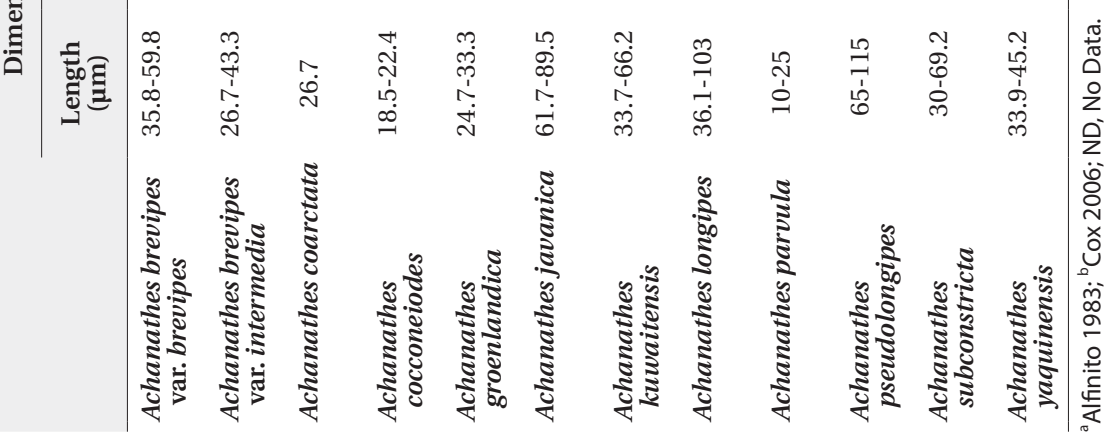




\section{Key to genus Achnanthes species}

1a. One row of striae on the raphid valve (RV) and araphid valve (ARV) ...2

1b. Multi-rows of striae on the RV and ARV . ...9

2a. Spines and marginal ridge on the valves A. yaquinensis

$2 \mathrm{~b}$. No spines and marginal ridge on the valves .................3 3a. Cuneate valve apices ............... A. brevipes var. brevipes 3 b. No cuneate valve apices ....4 4a. Terminal obiculi on the ARV ....5

4b. No terminal obiculi on the ARV ...................................6 5a. Internal costae inner valve .................... A. kuwaitensis 5b. No internal costae inner valve ..................... A. parvula 6a. Narrowed rostrate valve apices ................... A. coarctata 6b. Rounded rostrate valve apices

7a. Broad middle part of the valve ...............A. cocconeioides

7b. Not broad middle part of the valve . .8

8a. Striae in $10 \mu \mathrm{m}$ on the RV more than the ARV A. brevipes var. intermedia 8b. Striae in $10 \mu \mathrm{m}$ on the RV less than the ARV

A. groenlandica

9a. Terminal obiculi on the ARV .... .. 10

9b. No terminal obiculi on the ARV...... . .11

10a. Rows of striae on the RV differ the ARV.

A. pseudolongipes

10b. Rows of striae on the RV same the ARV

A. subconstricta

11a. Marginal ridge of the valve. A. javanica

11b. No marginal ridge of the valve A. longipes

\section{Descriptions of species}

Achnanthes brevipes var. brevipes Agardh (Fig. 1A-1E, Fig. 3A)

Synonym: Achnanthidium brevipes (Agardh) Cleve 1895; Achnantella brevipes (Agardh) Gaillon 1833; Achnanthidium brevipes (Agardh) Heiberg 1863.

Description: Valves linear-elliptical, slightly constricted in the middle, cuneate at the apices. In girdle view, valve slightly curved geniculately with a convex ARV and a concave RV. 35.8-59.8 $\mu \mathrm{m}$ long, 10.8-28.4 $\mu \mathrm{m}$ wide. Striae uniseriate on both valves (ARV and RV) with nine striae in $10 \mu \mathrm{m}$ on the ARV, and 10 striae in $10 \mu \mathrm{m}$ on the RV. Internal valves with thickened transverse costae. Transapical striae slightly radial. Cells without spines and marginal ridge. Both valves without terminal obiculi.

Distribution: A. brevipes var. brevipes is found all coastal areas and in salterns (Hustedt 1931), is common in estuaries or harbours and has been reported on the south and east coasts of Britain (Hendey 1964). Presently, A. brevipes var. brevipes was present 14 times in Korean coastal waters in planktonic environments: ES-01 (21 Jan 2009), ES-02 (21 Jan 2009), ES-19 (23 Jan 2009), ES-24 (16 Feb 2009), ES-32 (29 Aug 2010), ES-37 (29 Aug 2010), ES-40 (29 Aug 2010), ES-51 (30 Aug 2010), ES-53 (21 Apr 2013), YS-12 (24 Jul 2010), SS-01 (15 Nov 2010), SS-06 (16 Nov 2010), SS-09 (9 Jun 2011), SS-21 (26 Feb 2013).

References: Agardh 1824, p 1; Gaillon 1833, p 10; Heiberg 1863, p 118; Cleve 1895, p 193; Hendey 1951, p 41, pl. 16, figs. 9, 10.

Remarks: This species possesses the thickened transverse costae on the internal valves (Alfinito 1983), although it was not examined in this study. A. brevipes var. brevipes is dissimilar to A. brevipes var. intermedia in possessing more narrowed valve ends.

\section{Achnanthes brevipes var. intermedia (Kützing) Cleve} (Fig. 1I-1K)

Basionym: Achnanthes intermedia Kützing 1833.

Synonym: Achnanthes intermedia Kützing 1833; Achnanthes subsessilis Kützing 1833; Achnanthidium brevipes var. intermedia '(Kützing) Cleve' VanLandingham 1967.

Description: Valves linear-elliptical, sometimes slightly constricted in the middle, rounded at the apices. In girdle view, the valve is slightly curved geniculately, with a convex ARV and a concave RV. 26.7-43.3 $\mu \mathrm{m}$ long, 9.2-11.3 $\mu \mathrm{m}$ wide. Striae uniseriate on both valves (ARV and RV) with 10 striae in $10 \mu \mathrm{m}$ on the ARV and 11-12 striae in $10 \mu \mathrm{m}$ on the RV. Transapical striae slightly radial. Cells without spines and marginal ridge. Both valves without terminal obiculi.

Distribution: A. brevipes var. intermedia are widely distributed and lives in waters of lower salt concentration (Hustedt 1931). McIntire and Reimer (1974) found the species from Yaquina Estuary, Oregon, in Aug 1968, Oct 1968 and Jul 1969. Presently, A. brevipes var. intermedia was recorded 16 times as a planktonic diatom of East Sea and Yellow Sea: ES-04 (22 Jan 2009), ES-08 (22 Jan 2009), ES-14 (22 Jan 2009), ES-30 (28 Aug 2010), ES-34 (29 Aug 2010), ES-37 (29 Aug 2010), ES-38 (29 Aug 2010), ES-39 (29 Aug 2010), ES-41 (29 Aug 2010), ES-42 (29 Aug 2010), ES48 (30 Aug 2010), YS-04 (22 Jul 2010), YS-05 (22 Jul 2010), YS-08 (23 Jul 2010), YS-11 (23 Jul 2010), YS-14 (24 Jul 2010).

References: Cleve 1895, p 193; Kützing 1833, p 576, figs. 55, 56; VanLandingham 1967, p 70; McIntire and Reimer 1974, p 171, pl. II, fig. 8a-b, pl. III, fig. 2a-b.

Remarks: Thickened transverse costae of $A$. brevipes var. intermedia was not examined in this study. 

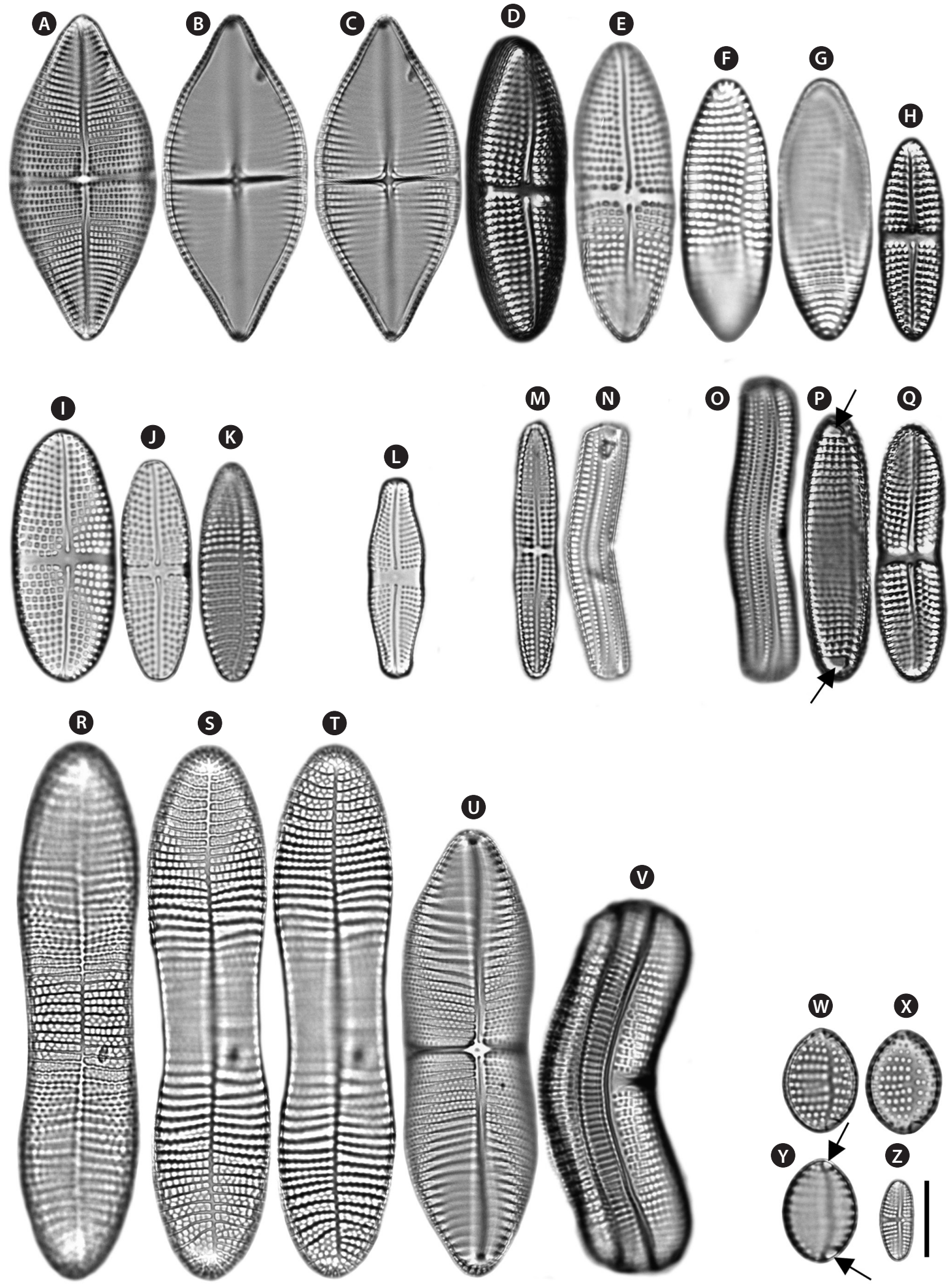

Fig. 1. LM microphotographs of the Achnanthes spp. (A-E) RV of the A. brevipes var. brevipes. (I-K) RV of the A. brevipes var. intermedia. (L) RV of the A. coarctata. (M) RV of the A. groenlandica. (N) Girdle view of the A. groenlandica. (O) Girdle view of the A. kuwaitensis. (P) ARV with terminal obiculi (arrows) of the A. kuwaitensis. (Q) RV of the A. kuwaitensis. (R-T) ARV of the A. longipes. (U) RV of the A. longipes. (V) Girdle view of the A. longipes. (W-Y) ARV with terminal obiculi (arrows) of the A. parvula. (Z) RV of the A. parvula. Scale bar, $10 \mu \mathrm{m}$. 

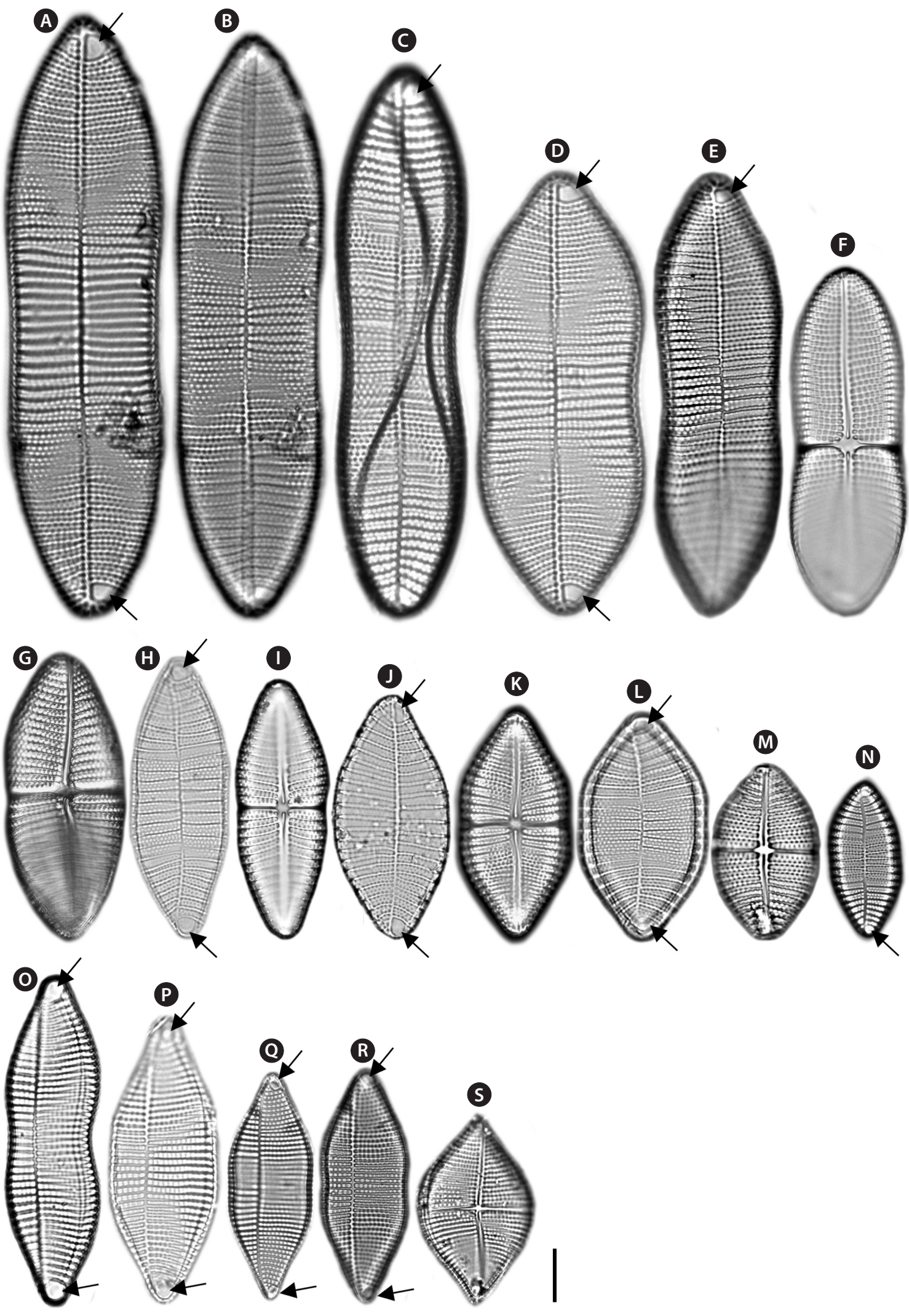

Fig. 2. LM microphotographs of the Achnanthes spp. (A-E) ARV with terminal obiculi (arrows) of the A. pseudolongipes. (F) RV of the A. pseudolongipes. (G, $\mathrm{I}, \mathrm{K} \& \mathrm{M}$ ) RV of the A. subconstricta. ( $\mathrm{H}, \mathrm{J}, \mathrm{L} \& \mathrm{~N}$ ) ARV with terminal obiculi (arrows) of the A. subconstricta. (O-R) ARV with terminal obiculi (arrows) of the $A$. yaquinensis. (S) RV of the $A$. yaquinensis. Scale bar, $10 \mu \mathrm{m}$. 


\section{Achnanthes coarctata (Brébisson ex Smith) Cleve \& Grunow (Fig. 1L) \\ Basionym: Achnanthidium coarctatum Brébisson ex Smith 1855.}

Synonym: Achnanthidium coarctatum Brébisson ex Smith 1855.

Description: Valves linear-elliptical, constricted in the middle, with narrowed rostrate at the apices. In girdle view, the valve is slightly curved geniculately, with a convex ARV and a concave RV. $26.7 \mu$ m long, $7.3 \mu \mathrm{m}$ wide. Striae uniseriate on both valves (ARV and RV) with 10 costae in $10 \mu \mathrm{m}$ on the ARV and 10-12 costae in $10 \mu \mathrm{m}$ on the RV. Internal valves without thickened transverse costae. Transapical striae slightly radial. Cells without the spines and marginal ridge. Both valves without terminal obiculi.

Distribution: Hustedt (1931) found this species commonly in drainage ditches and on wet rocks from northern Europe. Cox (2006) examined $A$. coarctata on a SEM stub from Kinloch Rannoch, Perthshire, Scotland in Jul 2002. This study, A. coarctata was found in planktonic environment of East Sea only: ES-45 (29 Aug 2010).

References: Smith 1855, p 8, pl. 1, fig. 10; Cleve and Grunow 1880, p 121.

Remarks: Cox (2006) supposed it may be present spines or ridges at the face-mantle junction of the ARV such as $A$. yaquinensis; this was not examined presently. This species does not possess thickened transverse costae on the internal valves (Cox 2006), although it was not examined in this study.

\section{Achnnathes cocconeioides Riznyk (Fig. 3B-3C)}

Description: Valves elliptical, broad in the middle, rounded at the apices. In girdle view, the valve is nearly flat. 18.5-22.4 $\mu \mathrm{m}$ long, 6.9-11.8 $\mu \mathrm{m}$ wide. Striae uniseriate on the both valves (ARV and RV) with 10-11 striae in 10 $\mu \mathrm{m}$ on the ARV and 9-10 striae in $10 \mu \mathrm{m}$ on the RV. Transapical striae slightly radial. Cells without spines and marginal ridge. Both valves without terminal obiculi.

Distribution: Mclntire and Reimer (1974) recorded $A$. cocconeioides from the Yaquina Estuary, Oregon, in Aug 1968, Oct 1968, Feb 1969, May 1969, and Jul 1969. Presently, A. cocconeioides was identified as a planktonic diatom once from East Sea only: ES-35 (29 Aug 2010).

References: Riznyk 1973, p 114, 115, pl. I, figs. 8, 9, pl. 18, figs. 1, 2; McIntire and Reimer 1974, p 172, pl. II, fig. 7a-b, pl. IV, fig. 2a-b.

Remarks: The shape of the central area and the lack of terminal orbiculi distinguish this species from A. groenlandica and A. parvula. In addition, A. cocconeioides is characterized by its nearly flat raphe valve. This taxon is newly identified in Korea. Thickened transverse costae of A. coccorneioides was not examined in this study.

Achnanthes groenlandica Cleve \& Grunow (Fig. 1M, 1N, Fig. 3D-3F)

Basionym: Achnanthidium groenlandicum Cleve 1873. Synonym: Achnanthidium groenlandicum Cleve 1873; Achnanthepyla groenlandica Peragallo 1921.

Description: Valves linear, slightly convex in the middle, bluntly rounded at the apices. In girdle view, the valve is slightly curved geniculately, with a convex ARV and a concave RV. 24.7-33.3 $\mu \mathrm{m}$ long, 3.8-5.3 $\mu \mathrm{m}$ wide. Striae uniseriate on both valves (ARV and RV) with 13 striae in $10 \mu \mathrm{m}$ on the ARV and 12 striae in $10 \mu \mathrm{m}$ on the RV. Internal valves without thickened transverse costae. Transapical striae slightly radial. Cells without spines and marginal ridge. Both valves without terminal obiculi.

Distribution: Cox (2006) examined A. groelandica on a SEM stub collected in south of Cape Columbine, Cape Province, South Africa, in Jul 2002. Presently, A. groenladica was recorded seven times as a planktonic diatom in Korean coastal waters: ES-08 (22 Jan 2009), ES-17 (23 Jan 2009), ES-20 (23 Jan 2009), ES-32 (29 Aug 2009), ES-33 (29 Aug 2010), ES-40 (29 Aug 2009), YS-18 (15 Oct 2010), SS-11 (9 Jun 2011), SS-12 (10 Jun 2011), SS-17 (10 Jun 2011).

References: Cleve and Grunow 1880, p 20; Peragallo 1921, p 10; Cleve 1873, p 25, pl. 4, fig. 23.

Remarks: Cox (2006) supposed the striae pores of this taxon on the ARV may be markedly larger than on the RV. This was not examined in the present study. This species was newly recorded in Korean coastal waters. This species does not possess thickened transverse costae on the internal valves (Cox 2006), although it was not examined in this study.

\section{Achnanthes javanica Cleve \& Grunow (Fig. 4A-4C)}

Description: Valves linear-elliptical, slightly broad in the middle, cuneate at the apices. In girdle view, the valve is slightly curved geniculately, with a convex ARV and a concave RV. 61.7-89.5 $\mu \mathrm{m}$ long, 23.3-31.4 $\mu \mathrm{m}$ wide. Striae bi- or triseriate on the both valves (ARV and RV) with 5-6 striae in $10 \mu \mathrm{m}$ on the ARV and 5-6 striae in $10 \mu \mathrm{m}$ on the RV. Internal valves with thickened transverse costae. Transapical striae slightly radial. Cells with the marginal ridge but no spines. Both valves without terminal obiculi.

Distribution: Toyoda et al. (2003) examined A. javanica from the littoral area in Yonehara-Beach, Okinawa, Japan, in Mar 1996. Cox (2006) studied this species with a slide from Java. This study, A. javanica was present twice times in planktonic environments of the East Sea only: ES-10 

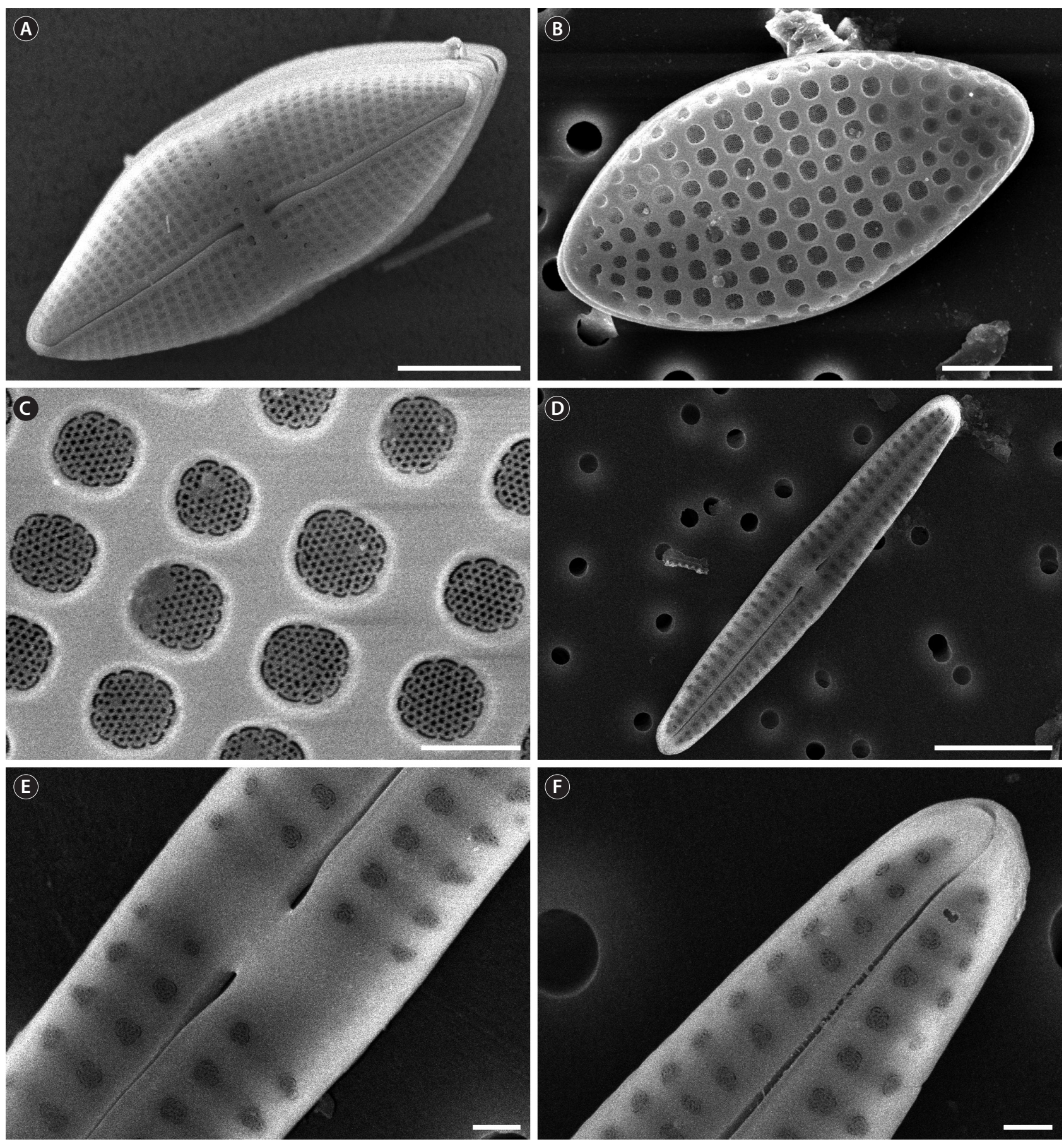

Fig. 3. SEM microphotographs of the Achnanthes spp. (A) RV of the A. brevipes var. brevipes. (B) Cribrate areolae on the RV of the A. cocconeioides. (C) Striae of the A. cocconeioides. (D) RV of the A. groenlandica. (E) Central area of RV of the A. groenlandica. (F) Terminal end of ARV of the A. groenlandica. Scale bars represent: $A, D, 10 \mu \mathrm{m} ; B, 5 \mu \mathrm{m} ; C, E, F, 1 \mu \mathrm{m}$.

(22 Jan 2009), ES-11 (22 Jan 2009).

References: Cleve and Grunow 1880, p 18; Toyoda et al. 2003, p 367, figs. 5-10, 21-28.

Remarks: A. javanica was newly recorded in Korean coastal waters.
Achnanthes kuwaitensis Hendey (Fig. 10-1Q, Fig. 4D-4F)

Synonym: Achnanthidium kuwaitensis 'Hendey' VanLandingham 1967.

Description: Valves nearly linear, slightly constricted in the middle, smoothly rounded at the apices. In girdle 
view, the valve is slightly curved geniculately, with a convex ARV and a concave RV. 33.7-66.2 $\mu \mathrm{m}$ long, 8.3-8.9 $\mu \mathrm{m}$ wide. Striae uniseriate on both valves (ARV and RV) with 10-11 striae in $10 \mu \mathrm{m}$ on the ARV and 9-11 striae in $10 \mu \mathrm{m}$ on the RV. Internal valves with thickened transverse costae. Transapical striae nearly linear. Cells without marginal ridge and spines. Terminal orbiculi with both ends of the ARV but not on the RV.

Distribution: Mclntire and Reimer (1974) reported this species from the Yaquina Estuary, Oregon (U.S.A.) in Aug 1968, Oct 1968, and Jul 1969. Presently, A. kuwaitensis was recorded eight times as a planktonic diatom from East Sea and Yellow Sea: ES-11 (22 Jan 2009), ES-13 (22 Jan 2009), ES-31 (29 Aug 2010), ES-32 (29 Aug 2010), ES-52 (26 Feb 2013), YS-16 (24 Jul 2010), YS-18 (15 Oct 2010), SS-21 (26 Feb 2013).

References: Hendey 1958, p 55, pl. 6, figs. 8-10; VanLandingham 1967, p 73; McIntire and Reimer 1974, p 173, pl. II, fig. 6a-c, pl. III, fig. 4a-b.

Remarks: This taxon can be easily distinguished from other linear shaped Achnanthes species by the terminal obiculi on the ends of ARV.

\section{Achnanthes longipes Agardh (Fig. 1R-1V, Fig. 4H-4K) \\ Synonym: Achnantella longipes Gaillon 1833.}

Description: Valves linear, slightly constricted in the middle, wedged at the apices. In girdle view, the valve is slightly curved geniculately, with a convex ARV and a concave RV. 36.1-103 $\mu \mathrm{m}$ long, 11.2-23.1 $\mu \mathrm{m}$ wide. Striae biseriate on both valves (ARV and RV) with 6-8 striae in $10 \mu \mathrm{m}$ on the ARV and 6-12 striae in $10 \mu \mathrm{m}$ on the RV. Internal valves with thickened transverse costae. Transapical striae nearly linear or slightly radial. Cells without marginal ridge and spines. Both valves without terminal obiculi.

Distribution: Cox (2006) studied A. longipes collected from Java. Presently, A. longipes was present 39 times in planktonic environments of Korean coastal waters: ES-01 (21 Jan 2009), ES-02 (21 Jan 2009), ES-03 (22 Jan 2009), ES05 (22 Jan 2009), ES-06 (22 Jan 2009), ES-07 (22 Jan 2009), ES-08 (22 Jan 2009), ES-09 (22 Jan 2009), ES-15 (23 Jan 2009), ES-18 (23 Jan 2009), ES-19 (23 Jan 2009), ES-20 (23 Jan 2009), ES-21 (23 Jan 2009), ES-22 (16 Feb 2009), ES-23 (16 Feb 2009), ES-24 (16 Feb 2009), ES-25 (16 Feb 2009), ES-27 (16 Feb 2009), ES-28 (16 Feb 2009), ES-29 (28 Aug 2010), ES-30 (28 Aug 2010), ES-31 (29 Aug 2010), ES-34 (29 Aug 2010), ES-40 (29 Aug 2010), ES-41 (29 Aug 2010), ES-43 (29 Aug 2010), ES-44 (29 Aug 2010), ES-45 (29 Aug 2010), ES-46 (29 Aug 2010), ES-47 (29 Aug 2010), ES-49 (30 Aug 2010), ES-53 (21 Apr 2013), YS-16 (24 Jul 2010), YS-17 (14 Oct 2010), SS-09 (9 Jun 2011), SS-15 (10 Jun 2011), SS-
16 (10 Jun 2011), SS-17 (10 Jun 2011), SS-18 (11 Jun 2011). References: Agardh 1824, p 1; Gaillon 1833, p 10.

Remarks: A. longipes and A. pseudolongipes have large, longitudinal, panduriform valves and form long colonies attached to a long stalk, but lack ridges and spines. There is little difference between the two species, with the exception of an extra row of striae between the transverse costae on the RV.

\section{Achnanthes parvula Kützing (Fig. 1W-1Z, Fig. 5A)}

Synonym: Achnanthes brevipes var. parvula (Kützing) Cleve 1895; Achnanthidium brevipes var. parvulum '(Kützing) Cleve' VanLandingham 1967; Achnanthidium brevipes var. parvulum (Kützing) Mereschkowsky 1901.

Description: Valves linear-elliptical, slightly broad in the middle, rounded at the apices. In girdle view, the valve is slightly curved geniculately, with a convex ARV and a concave RV. 10-25 $\mu \mathrm{m}$ long, 4.7-9.2 $\mu \mathrm{m}$ wide. Striae uniseriate on both valves (ARV and RV) with 10-11 striae in $10 \mu \mathrm{m}$ on the ARV and $15-16$ striae in $10 \mu \mathrm{m}$ on the RV. Internal valves without thickened transverse costae. Transapical striae nearly linear or slightly radial. Cells without marginal ridge and spines. Terminal orbiculi with both ends of the ARV but not on the RV.

Distribution: Mclntire and Reimer (1974) recorded $A$. parvula from the Yaquina Estuary, Oregon in Aug 1968, Oct 1968, Feb 1969, May 1969, and Jul 1969. This study, $A$. parvula was recorded 6 times from planktonic environments of East Sea only: ES-01 (21 Jan 2009), ES-08 (22 Jan 2009), ES-09 (22 Jan 2009), ES-16 (23 Jan 2009), ES-17 (23 Jan 2009), ES-32 (29 Aug 2010).

References: Kützing 1844, p 76, pl. 21, fig. 5; Cleve 1895, p 193; VanLandingham 1967, p 71; Mereschkowsky 1901, p 31 .

Remarks: This taxon ostensibly resembles A. groenlandica, but is easily distinguished by the terminal orbiculi, which are lacking in A. groenlandica. The more precise name for this taxon is still uncertain. We are currently investigating this problem and intend to report on it in the near future. A. parvula was a newly record species in this study.

\section{Achnanthes pseudolongipes Toyoda \& Nagumo in Toyoda et al. (Fig. 2A-2F)}

Description: Valves linear-elliptical, constricted in the middle, cuneate at the apices. In girdle view, the valve is slightly curved geniculately, with a convex ARV and a concave RV. 65-115 $\mu \mathrm{m}$ long, 20.8.-29.1 $\mu \mathrm{m}$ wide. Striae bi- to triseriate with 6-7 striae in $10 \mu \mathrm{m}$ on the ARV, uniseriate with 4-5 striae in $10 \mu \mathrm{m}$ on the RV. Internal valves with 

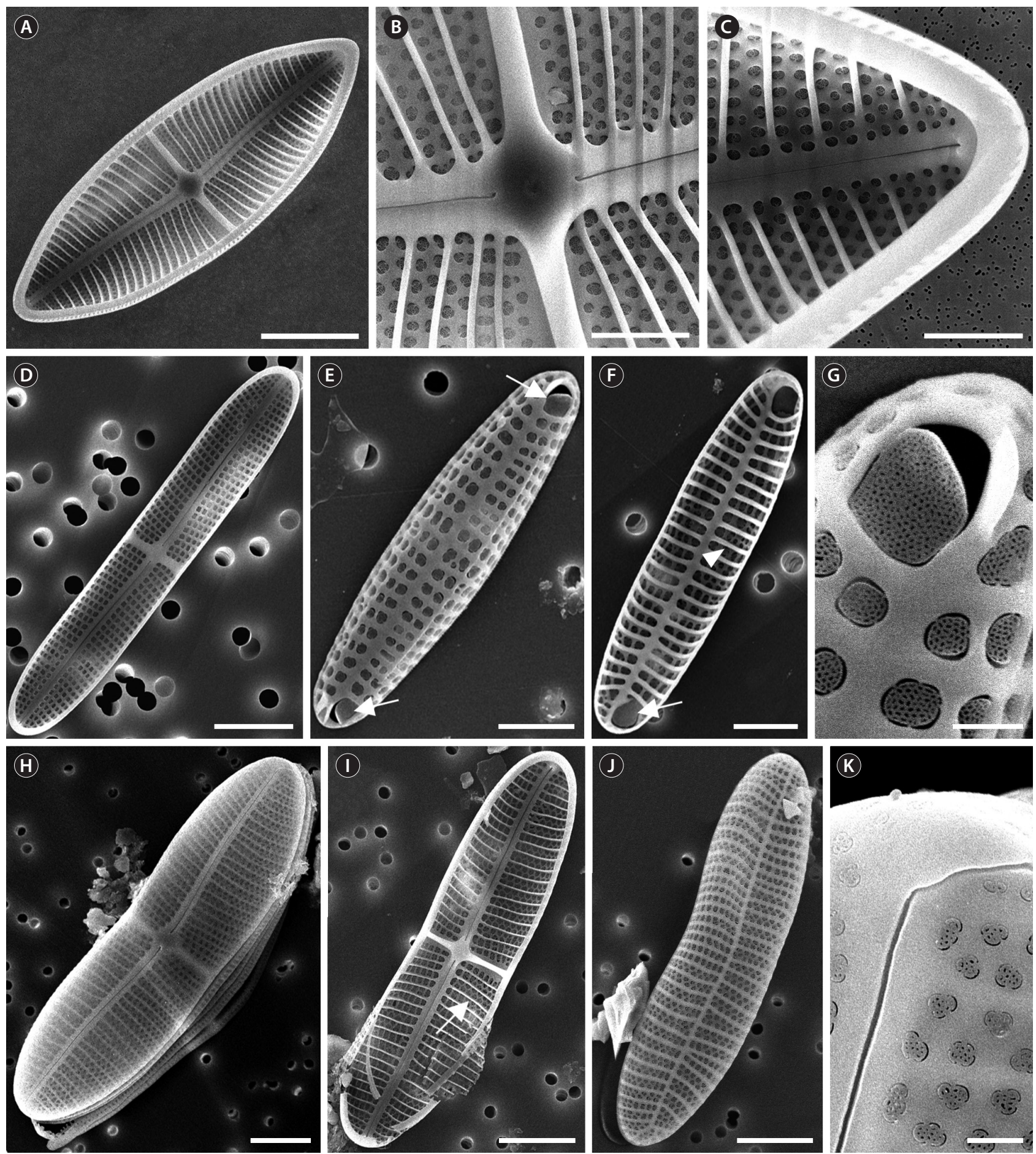

Fig. 4. SEM microphotographs of the Achnanthes spp. (A) Internal view of RV of the A. javanica. (B) Central area (stauros) of RV of the A. javanica. (C) Terminal end and costae of RV of the A. javanica. (D) Internal RV of the A. kuwaitensis. (E) ARV with terminal obiculi (arrows) of the A. kuwaitensis. (F) Internal ARV with terminal obiculi (arrows) and costae (arrowhead) of the A. kuwaitensis. (G) Terminal obiculi of the A. kuwaitensis. (H) RV of the A. longipes. (I) Internal RV with costae (arrow) of the A. longipes. (J) External RV of the A. longipes. (K) Raphe ending of the A. longipes. Scale bars represent: A, $20 \mu \mathrm{m} ; \mathrm{B}, \mathrm{C}, \mathrm{E}$, $\mathrm{F}, 5 \mu \mathrm{m} ; \mathrm{D}, \mathrm{H}-\mathrm{J}, 10 \mu \mathrm{m} ; \mathrm{G}, \mathrm{K}, 1 \mu \mathrm{m}$. 
thickened transverse costae. Transapical striae slightly radial. Cells without the marginal ridge and spines. Terminal orbiculi at both ends of the ARV but not on the RV.

Distribution: Toyoda et al. (2010) found A. pseudolongipes from a fishery buoy off the coast of Japan. Presently, A. pseudolongipes was present six times as a planktonic diatom from the East Sea only: ES-09 (22 Jan 2009), ES-16 (23 Jan 2009), ES-18 (23 Jan 2009), ES-40 (29 Aug 2010), ES-44 (29 Aug 2010), ES-50 (30 Aug 2010).

References: Toyoda et al. 2010, p 186, figs. 1-28.

Remarks: A. pseudolongipes is the only species known so far in Achnanthes sensu stricto to possess a different pattern of seriate striae; the ARV will have the same striae pattern (Toyoda et al. 2003, Toyoda and Williams 2004, Toyoda et al. 2005a). A. pseudolongipes is easily separated from these taxa by its plastid structure as well as the uniseriate striae of its RV (Toyoda et al. 2010). This species was newly recorded in this study. This species possesses thickened transverse costae on the internal valves (Cox 2006), although it was not examined in this study.

\section{Achnanthes subconstricta (Meister) Toyoda (Fig. 2G-2N,} Fig. 5B-5F)

Basionym: Achnanthes javanica var. subconstricta Meister 1932.

Description: Valves linear-elliptical, constricted in the middle, with cuneate at the apices. In girdle view, the valve is slightly curved geniculately, with a convex ARV and a concave RV. 30-69.2 $\mu \mathrm{m}$ long, 13.3-26.9 $\mu \mathrm{m}$ wide. Striae bi- to tetraseriate on the both valves (ARV and RV) with 4-5 striae in $10 \mu \mathrm{m}$ on the ARV and 5-6 striae in $10 \mu \mathrm{m}$ on the RV. Internal valves with thickened transverse costae. Transapical striae slightly radial. Cells with the marginal ridge and spines on the both terminal ends and marginal ridge of the valve. Terminal orbiculi with both ends of the ARV but not on the RV.

Distribution: Mclntire and Reimer (1974) recorded the species from the Yaquina Estuary, Oregon, in Aug 1968, and Jul 1969. Toyoda et al. (2003) examined A. subconstricta from littoral area of marine in Ohhara, Chiba, Japan in Mar, 1999 and littoral area of brackish in Kamegasaki, Chiba, Japan in Sep, 1999. Presently, A. subconstricta was recorded 38 times in planktonic environments of Korean coastal waters: ES-05 (22 Jan 2009), ES-06 (22 Jan 2009), ES-08 (22 Jan 2009), ES-10 (22 Jan 2009), ES-16 (23 Jan 2009), ES-21 (23 Jan 2009), ES-22 (16 Feb 2009), ES-29 (28 Aug 2010), ES-34 (29 Aug 2010), ES-36 (29 Aug 2010), ES37 (29 Aug 2010), ES-39 (29 Aug 2010), ES-52 (26 Feb 2013), YS-01 (22 Jul 2010), YS-02 (22 Jul 2010), YS-03 (22 Jul 2010), YS-04 (22 Jul 2010), YS-05 (22 Jul 2010), YS-06 (23 Jul 2010),
YS-07 (23 Jul 2010), YS-08 (23 Jul 2010), YS-09 (23 Jul 2010), YS-10 (23 Jul 2010), YS-13 (24 Jul 2010), YS-15 (24 Jul 2010), SS-01 (15 Nov 2010), SS-02 (15 Nov 2010), SS-03 (15 Nov 2010), SS-04 (16 Nov 2010), SS-05 (16 Nov 2010), SS-06 (16 Nov 2010), SS-07 (17 Nov 2010), SS-08 (9 Jun 2011), SS-10 (9 Jun 2011), SS-13 (10 Jun 2011), SS-14 (10 Jun 2011), SS19 (11 Jun 2011), SS-20 (11 Jun 2011), SS-21 (26 Feb 2013).

References: Toyoda et al. 2003, p 369; Meister 1932, p 40, pl. 14, fig. 113.

Remarks: This taxon is very similar in shape to $A$. longipes, particularly the larger cells. It is best distinguished by the single rows of areolae and particularly by the terminal orbiculi which are absent in A. longipes. Toyoda et al. (2003) suggested that A. javanica and A. subconstricta could be recognized as separate species. The most significant distinguishing character is the presence of terminal orbiculi in A. subconstricta.

Achnanthes yaquinensis McIntire \& Reimer (Fig. 2O-2S, Fig. 5G-5I)

Description: Valves nearly rhombus, smoothly rounded in the middle, cuneate at the apices. In girdle view, the valve is slightly curved geniculately, with a convex ARV and a concave RV. 33.9-45.2 $\mu \mathrm{m}$ long, 9.2-27.2 $\mu \mathrm{m}$ wide. Striae uniseriate on the both valves (ARV and RV) with 8-8.5 striae in $10 \mu \mathrm{m}$ on the ARV and 8-9 striae in $10 \mu \mathrm{m}$ on the RV. Internal valves with thickened transverse costae. Transapical striae nearly linear or slightly radial. Cells with the marginal ridge and spines on the both terminal ends of the valve. Terminal orbiculi with both end of the ARV but not on the RV.

Distribution: Mclntire and Reimer (1974) found A. yaquinensis from Yaquina Estuary, Oregon (U.S.A.) in Aug 1968, Oct 1968, May 1969, and Jul 1969. Toyoda et al. (2005b) found this species from the coast of Japan in Apr 1994, Nov 2001, and Jun 2001. This study, A. yaquinensis was found three times as a planktonic diatom from the East Sea only: ES-12 (22 Jan 2009), ES-26 (16 Feb 2009), ES-27 (16 Feb 2009).

References: McIntire and Reimer 1974, p 174, pl. II, fig. 1a-b, pl. III, fig. 1a-b.

Remarks: This taxon is very similar in shape to A. longipes, particularly the larger cells. It is best distinguished by the single rows of areolae and particularly by the terminal orbiculi which are absent in A. longipes. Also, this species resembles $A$. subconstricta; the valves are panduriform and the ARV has terminal orbiculi. However, the taxa can be easily be distinguished by the number of rows of areolae between the costae. A. yaquinensis has a single row, while $A$. subconstricta has more than three. In addi- 

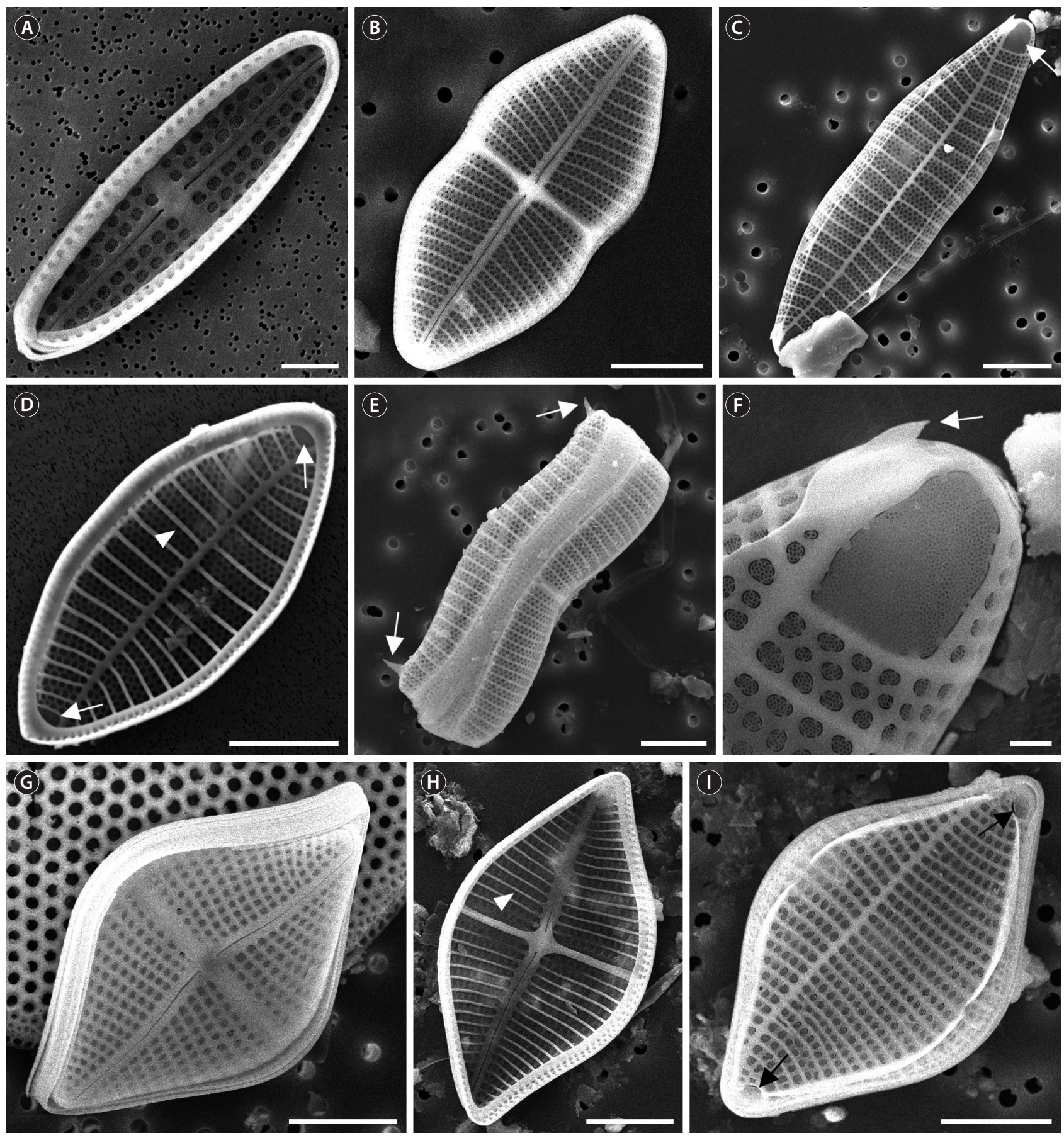

Fig. 5. SEM microphotographs of the Achnanthes spp. (A) Internal RV of the A. parvula. (B) RV of the A. subconstricta. (C) ARV with terminal obiculi (arrow) of the A. subconstricta. (D) Internal ARV with terminal obiculi (arrows) and costae (arrowhead) of the A. subconstricta. (E) Girdle view with terminal spines (arrows) of the ARV of the A. subconstricta. (F) Terminal obiculi and spine (arrow) of the A. subconstricta. (G) RV of the A. yaquinensis. (H) Internal RV with costae (arrow) of the A. yaquinensis. (I) ARV with terminal obiculi (arrows) of the A. yaquinensis. Scale bars represent: A, $2 \mu \mathrm{m} ; \mathrm{B}-\mathrm{E} \& \mathrm{G}-\mathrm{I}, 10 \mu \mathrm{m} ; \mathrm{F}, 1 \mu \mathrm{m}$. 
tion, A. subconstricta usually has some marginal spines that develop from the marginal ridge, while A. yaquinensis has only two terminal spines, one at each end of the ARV. This species was new record species in this study.

\section{CONCLUSION}

Twelve Achnanthes species including the seven newly recorded species (A. cocconeioides, A. groenlandica, A. javanica, A. kuwaitensis, A. parvula, A. pseudolongipes, and A. yaquinensis) were obtained in marine and brackish waters of Korea. They are assigned to the genus Achnanthes based on 11 key characteristics.

Most of Achnanthes species possessed the same rows of striae on RV and ARV, but A. pseudolongipes had the different rows of striae each valve. Internal costae were found in A. brevipes var. brevipes, A. javanica, A. kuwaitensis, A. longipes, A. pseudolongipes, A. subconstricta and A. yaquinensis, although Achnanthes coarctata, A. groenlandica and $A$. parvula had not internal costae of the valve. Internal costae of A. brevipes var. intermedia and A. cocconeioides were not confirmed in this study and other references. Spines and marginal ridge on the valve were found the both A. subconstricta and A. yaquinensis, but A. javanica had only the spines on the valve. Terminal obiculi on the valve were possessed A. kuwaitensis, A. parvula, A. pseudolongipes, A. subconstricta and A. yaquinenis. Therefore, A, subconstricta and A. yaquinensis possess internal costae, spines, marginal ridge on the valves and terminal obiculi on the ARV.

We present the distribution of Achnanthes species in this study. All Achnanthes species were found the East Sea, six species were recorded from the Yellow Sea, and four species were obtained from the South Sea. All unrecorded species were found from the East Sea, three unrecorded species were examined in the Yellow Sea, and three unrecorded species were found from the South Sea. From 92 sites, the most frequent species was A. longipes and $A$. subconstricta (39 times for each) and the least frequent species were $A$. coarctata and A. cocconeioides (once each), while the A. cocconeioides was the least common unrecorded species (once). Of the 92 stations, the site that involved the largest number of species $(n=5)$ in Korea was ES-08. Four species were obtained from ES-32 and three species each from ES-01, ES-09, ES-16, ES-34 and ES-37. One or two species were present in most sites. Of the newly recorded species, the sites that involved the large number of species in Korea were ES-08, ES-16 and ES-32 (three species at each site). Achnanthes species were more found from the East Sea than from the Yellow Sea or South Sea.

Consequently, valid nomenclatural-named Achnanthes taxa were 23 species including the seven unrecorded species in this study (Table 1). Further in-depth taxonomic studies of the other genera should be examined in marine, brackish and fresh water of Korea, although this paper will suffice to reestablish the taxonomic status of Achnanthes species in Korea.

\section{ACKNOWLEDGMENTS}

This work was supported by a grant from the National Institute of Biological Resources (NIBR), funded by the Ministry of Environment (MOE) of Republic of Korea (NIBR No. 2013-01-001) and by a 2013 Research Grant from Sangmyung University.

\section{LITERATURE CITED}

Agardh CA. 1824. Systema Algarum. xxxvii. Literis Berlingianis, Lundae.

Alfinito S. 1983. Ultrastructural study on Achnanthes brevipes Agardh (Bacillariophyceae) using the scanning electron microscope. Ann Bot (Roma) 41: 149-156.

Anonymous. 1975. Proposals for a standardization of diatom terminology and diagnoses. Nova Hedwigia Beiheft 53: 323-354.

Bory de Saint-Vincent JBM. 1822. Dictionnaire Classique d'Histoire Naturelle. Vol 1, Paris (Rey \& Gravier, ed). Baudouin Frères, Paris.

Cleve PT. 1873. On diatoms from the Arctic Sea. Vol 1. Bih Kongl Svenska Vetensk-Akad Handl, Stockholm.

Cleve PT. 1895. Synopsis of the naviculoid diatoms. Vol 27. Bih Kongl Svenska Vetensk-Akad Handl, Stockholm.

Cleve PT, Grunow A. 1880. Beiträge zur Kenntniss der Arctischen Diatomeen. Vol 17. Bih Kongl Svenska VetenskAkad Handl, Stockholm.

Cox EJ. 2006. Achnanthes sensu stricto belongs with genera of the Mastogloiales rather than with other monoraphid diatoms (Bacillariophyta). Eur J Phycol 41: 67-81.

Gaillon B. 1833. Aperçu d'histoire naturelle et observations sur les limites qui séparent le règne végétal du règne animal tableaux synoptiques et méthodiques des genres des nématozoaires. Vol 51. Imprimerie de LeRoy-Mabille, Boulogne-sur-mer.

Hasle GR, Fryxell GA. 1970. Diatoms: cleaning and mounting for light and electron microscopy. Trans Am Microsc 
Soc 89: 469-474.

Heiberg PAC. 1863. Conspectus criticus Diatomacearum Danicarum. Kritisk Oversigt over De Danske Diatomeer. Wilhelm Priors Forlag, Kjøbenhavn.

Hendey NI. 1951. Littoral diatoms of Chichester Harbour with special reference to fouling. J Royal Microscop Soc 71: 1-86.

Hendey NI. 1958. Marine Diatoms from some West African ports. J Royal Microscop Soc 77: 28-85.

Hendey NI. 1964. An introductory account of the smaller algae of British coastal waters. Part V, Bacillariophyceae (diatoms). HMSO, London.

Hustedt F. 1931. Die Kieselalgen Deutschlands, Österreichs und der Schweiz. In: Kryptogamen-Flora von Deutschlands, Oesterreichs und der Schweiz (Rabenhorst L, ed). Akademische Verlagsgesellschaft m.b.h, Leipzig, pp 609-920.

Kützing FT. 1833. Synopsis Diatomacearum oder Versuch einer systematischen Zusammenstellung der Diatomeen. Linnaea 8: 529-620.

Kützing FT. 1844. Die Kieselschaligen Bacillarien oder Diatomeen. Zu finden bei W. Köhne, Nordhausen.

Lee JH. 1995. Additional check-list of marine planktonic algae in the coastal waters of Korea. I. Bacillariophyceae. J Nat Sci Sangmyung Women's Univ 2: 71-198.

Lee K, Choi JK, Lee JH. 1995. Taxonomic studies on diatoms in Korea. II. Check-list. Kor J Phycol Suppl 10: 13-89.

McIntire CD, Reimer CW. 1974. Some marine and brackishwater Achnanthes from Yaquina Estuary, Oregon (USA). Bot Mar 17: 164-175.

Meister F. 1932. Kieselalgen aus Asien. Verlag von Gebrüder Borntraeger, Berlin.

Mereschkowsky C. 1901. Etjudy nad endokhromom diatomovykh vodoroslei (po frants). (Etude sur l'endochrome des Diatomées.) I. Zapiski Imperatorskoj Akademii Nauk po Fiziko-matematiceskomee Otdeleniju. Memoires de l'academie imperiale des sciences, Classe physicomathematique. Imperatorskaâ Akademiâ Nauk, Saint Petersbourg 11: 1-40.

Peragallo M. 1921. Diatomées d'eau douce et Diatomées d'eau salée. Deuxième Expédition Antarctique Française (1908-1910) commandée par le Dr. Jean Charcot, Sciences Naturelles: Documents Scientifiques, Botanique. Masson et Cie, Paris.

Riznyk RZ. 1973. Interstitial diatoms from two tidal flats in Yaquina Estuary, Oregon, USA. Bot Mar 16: 113-138.

Ross R, Cox EJ, Karayeva NI, Mann DG, Paddock TBB, Si- monsen R, Sims PA. 1979. An amended terminology for the siliceous components of the diatom cell. Nova Hedwigia Beiheft 64: 513-533.

Round FE, Basson PW. 1997. A new monoraphid diatom genus (Pogoneis) from Bahrain and the transfer of previously described species. A. hungarica and A. taeniata to new genera. Diatom Res 12: 71-81.

Round FE, Bukhtiyarova L. 1996. Four new genera based on Achnanthes (Achnanthidium) together with a re-definition of Achanathidium. Diatom Res 11: 345-361.

Round FE, Crawford RM, Mann DG. 1990. The Diatoms: Biology and Morphology of the Genera. Cambridge University Press, Cambridge.

Smith W. 1855. Notes of an excursion to the south of France and the Auvergne in Search of Diatomaceae. Ann Mag Nat Hist 15: 1-9.

Sournia A. 1968. Diatomées planctoniques du canal de Mozambique et de I'lle Maurice. Mem ORSTOM 31: 1-120.

Toyoda K, Cox EJ, Sims PA, Williams DM. 2005a. The typification of Achnanthes Bory based on Echinella stipitata Lyngbye, with an account of the morphology and fine structure of Lyngbye's species. Diatom Res 20: 375-386.

Toyoda K, Idei M, Nagumo T, Tanaka J. 2005b. Fine-structure of the vegetative frustule, perizonium and initial valve of Achnanthes yaquinensis (Bacillariophyta). Eur J Phycol 40: 269-279.

Toyoda K, Nagumo T, Osada K, Tanaka J. 2003. Morphological investigations of Achnanthes javanica Grunow and A. subconstricta (Meister) comb. nov. Diatom Res 18: 365-375.

Toyoda K, Nagumo T, Williams DM. 2010. A new marine monoraphid species, Achnanthes pseudolongipes sp. nov., from Miyagi, Japan. Diatom Res 25: 185-193.

Toyoda K, Williams DM. 2004. Description of Achnanthes Bory (Bacillariophyceae) based on Kützing's type slides and materials I: new morphological information on Achnanthes brevipes var. intermedia (Kütz.) Cleve. Diatom 20: 159-165.

Toyoda K, Williams DM, Tanaka J, Nagumo T. 2006. Morphological investigations of the frustule, perizonium and initial valves of the freshwater diatom Achnanthes crenulata Grunow (Bacillariophyceae). Phycol Res 54: 173-182.

VanLandingham SL. 1967. Catalogue of the fossil and recent genera and species of diatoms and their synonyms. Part I. Acanthoceras through Bacillaria, Vol 1. Verlag von J Cramer, Lehre. 
Appendix 1. Sampling sites in coastal waters of Korea

\begin{tabular}{|c|c|c|c|c|}
\hline Date & Station & Locality & Latitude & Longitude \\
\hline 21 Jan 2009 & $E S^{1}-01$ & Dogu-ri, Donghae-myeon, Nam-gu, Pohang-si, Gyeongsangbuk-do & $35^{\circ} 59.839 \mathrm{~N}$ & $129^{\circ} 27.479 \mathrm{E}$ \\
\hline $21 \operatorname{Jan} 2009$ & ES-02 & Daebo-ri, Homigot-myeon, Nam-gu, Pohang-si, Gyeongsangbuk-do & $36^{\circ} 04.793 \mathrm{~N}$ & $129^{\circ} 33.596 \mathrm{E}$ \\
\hline 22 Jan 2009 & ES-03 & Duho-dong, Buk-gu, Pohang-si, Gyeongsangbuk-do & $36^{\circ} 03.703 \mathrm{~N}$ & $129^{\circ} 23.300 \mathrm{E}$ \\
\hline $22 \operatorname{Jan} 2009$ & ES-04 & Wolpo-ri, Cheongha-myeon, Buk-gu, Pohang-si, Gyeongsangbuk-do & $36^{\circ} 12.485 \mathrm{~N}$ & $129^{\circ} 22.496 \mathrm{E}$ \\
\hline $22 \operatorname{Jan} 2009$ & ES-05 & Jangsa-ri, Namjeong-myeon, Yeongdeok-gun, Gyeongsangbuk-do & $36^{\circ} 15.673 \mathrm{~N}$ & $129^{\circ} 22.493 \mathrm{E}$ \\
\hline 22 Jan 2009 & ES-06 & Samsa-ri, Ganggu-myeon, Yeongdeok-gun, Gyeongsangbuk-do & $36^{\circ} 21.430 \mathrm{~N}$ & $129^{\circ} 23.058 \mathrm{E}$ \\
\hline $22 \operatorname{Jan} 2009$ & ES-07 & Chuksan-ri, Chuksan-myeon, Yeongdeok-gun, Gyeongsangbuk-do & $36^{\circ} 30.505 \mathrm{~N}$ & $129^{\circ} 26.945 \mathrm{E}$ \\
\hline $22 \operatorname{Jan} 2009$ & ES-08 & Byeonggok-myeon, Yeongdeok-gun, Gyeongsangbuk-do & $36^{\circ} 35.907 \mathrm{~N}$ & $129^{\circ} 24.905 \mathrm{E}$ \\
\hline $22 \operatorname{Jan} 2009$ & ES-09 & Gusan-ri, Giseong-myeon, Uljin-gun, Gyeongsangbuk-do & $36^{\circ} 45.369 \mathrm{~N}$ & $129^{\circ} 28.168 \mathrm{E}$ \\
\hline $22 \operatorname{Jan} 2009$ & ES-10 & Mangyang-ri, Giseong-myeon, Uljin-gun, Gyeongsangbuk-do & $36^{\circ} 51.147 \mathrm{~N}$ & $129^{\circ} 25.673 \mathrm{E}$ \\
\hline $22 \operatorname{Jan} 2009$ & ES-11 & Sanpo-ri, Geunnam-myeon, Uljin-gun, Gyeongsangbuk-do & $36^{\circ} 57.907 \mathrm{~N}$ & $129^{\circ} 24.889 \mathrm{E}$ \\
\hline $22 \operatorname{Jan} 2009$ & ES-12 & Jukbyeon-myeon, Uljin-gun, Gyeongsangbuk-do & $37^{\circ} 01.961 \mathrm{~N}$ & $129^{\circ} 24.936 \mathrm{E}$ \\
\hline 22 Jan 2009 & ES-13 & Imwon-ri, Wondeok-eup, Samcheok-si, Gangwon-do & $37^{\circ} 13.523 \mathrm{~N}$ & $129^{\circ} 20.481 \mathrm{E}$ \\
\hline $22 \operatorname{Jan} 2009$ & ES-14 & Gungchon-ri, Geundeok-myeon, Samcheok-si, Gangwon-do & $37^{\circ} 19.630 \mathrm{~N}$ & $129^{\circ} 16.119 \mathrm{E}$ \\
\hline $23 \operatorname{Jan} 2009$ & ES-15 & Jeongha-dong, Samcheok-si, Gangwon-do & $37^{\circ} 19.630 \mathrm{~N}$ & $129^{\circ} 16.116 \mathrm{E}$ \\
\hline $23 \operatorname{Jan} 2009$ & ES-16 & Daejin-dong, Donghae-si, Gangwon-do & $37^{\circ} 34.924 \mathrm{~N}$ & $129^{\circ} 06.719 \mathrm{E}$ \\
\hline $23 \operatorname{Jan} 2009$ & ES-17 & Jeongdongjin-ri, Gangdong-myeon, Gangneung-si, Gangwon-do & $37^{\circ} 41.163 \mathrm{~N}$ & $129^{\circ} 02.570 \mathrm{E}$ \\
\hline $23 \operatorname{Jan} 2009$ & ES-18 & Sacheonjin-ri, Sacheon-myeon, Gangneung-si, Gangwon-do & $37^{\circ} 41.162 \mathrm{~N}$ & $129^{\circ} 02.569 \mathrm{E}$ \\
\hline $23 \operatorname{Jan} 2009$ & ES-19 & Namae-ri, Hyeonnam-myeon, Yangyang-gun, Gangwon-do & $37^{\circ} 41.162 \mathrm{~N}$ & $129^{\circ} 02.569 \mathrm{E}$ \\
\hline $23 \operatorname{Jan} 2009$ & ES-20 & Dongmyeong-dong, Sokcho-si, Gangwon-do & $38^{\circ} 12.640 \mathrm{~N}$ & $128^{\circ} 25.771 \mathrm{E}$ \\
\hline $23 \operatorname{Jan} 2009$ & ES-21 & Oho-ri, Jugwang-myeon, Goseong-gun, Gangwon-do & $38^{\circ} 19.607 \mathrm{~N}$ & $128^{\circ} 31.708 \mathrm{E}$ \\
\hline 16 Feb 2009 & ES-22 & Gwangan-dong, Suyeong-gu, Busan & $35^{\circ} 08.317 \mathrm{~N}$ & $129^{\circ} 06.867 \mathrm{E}$ \\
\hline 16 Feb 2009 & ES-23 & Ilgwang-myeon, Gijang-gun, Busan & $35^{\circ} 21.313 \mathrm{~N}$ & $129^{\circ} 21.255 \mathrm{E}$ \\
\hline 16 Feb 2009 & ES-24 & Seosaeng-myeon, Ulju-gun, Ulsan & $35^{\circ} 21.315 \mathrm{~N}$ & $129^{\circ} 21.256 \mathrm{E}$ \\
\hline 16 Feb 2009 & ES-25 & Hwangseong-dong, Nam-gu, Ulsan & $35^{\circ} 37.113 \mathrm{~N}$ & $129^{\circ} 27.009 \mathrm{E}$ \\
\hline 16 Feb 2009 & ES-26 & Jeongja-dong, Buk-gu, Ulsan & $35^{\circ} 41.585 \mathrm{~N}$ & $129^{\circ} 28.522 \mathrm{E}$ \\
\hline 16 Feb 2009 & ES-27 & Oryu-ri, Gampo-eup, Gyeongju-si, Gyeongsangbuk-do & $35^{\circ} 52.679 \mathrm{~N}$ & $129^{\circ} 31.136 \mathrm{E}$ \\
\hline 16 Feb 2009 & ES-28 & Yangpo-ri, Janggi-myeon, Nam-gu, Pohang-si, Gyeongsangbuk-do & $38^{\circ} 13.200 \mathrm{~N}$ & $128^{\circ} 35.406 \mathrm{E}$ \\
\hline 28 Aug 2010 & ES-29 & Dogu-ri, Donghae-myeon, Nam-gu, Pohang-si, Gyeongsangbuk-do & $35^{\circ} 59.801 \mathrm{~N}$ & $129^{\circ} 27.470 \mathrm{E}$ \\
\hline 28 Aug 2010 & ES-30 & Duho-dong, Buk-gu, Pohang-si, Gyeongsangbuk-do & $36^{\circ} 03.812 \mathrm{~N}$ & $129^{\circ} 23.258 \mathrm{E}$ \\
\hline 29 Aug 2010 & ES-31 & Cheongha-myeon, Buk-gu, Pohang-si, Gyeongsangbuk-do & $36^{\circ} 12.491 \mathrm{~N}$ & $129^{\circ} 22.553 \mathrm{E}$ \\
\hline 29 Aug 2010 & ES-32 & Ganggu-ri, Ganggu-myeon, Yeongdeok-gun, Gyeongsangbuk-do & $36^{\circ} 21.560 \mathrm{~N}$ & $129^{\circ} 23.141 \mathrm{E}$ \\
\hline 29 Aug 2010 & ES-33 & Daetan-ri, Yeongdeok-eup, Yeongdeok-gun, Gyeongsangbuk-do & $36^{\circ} 26.505 \mathrm{~N}$ & $129^{\circ} 26.006 \mathrm{E}$ \\
\hline 29 Aug 2010 & ES-34 & Chuksan-ri, Chuksan-myeon, Yeongdeok-gun, Gyeongsangbuk-do & $36^{\circ} 30.464 \mathrm{~N}$ & $129^{\circ} 26.975 \mathrm{E}$ \\
\hline 29 Aug 2010 & ES-35 & Byeonggok-ri, Byeonggok-myeon, Yeongdeok-gun,Gyeongsangbuk-do & $36^{\circ} 35.949 \mathrm{~N}$ & $129^{\circ} 24.907 \mathrm{E}$ \\
\hline 29 Aug 2010 & ES-36 & Hupo-ri, Hupo-myeon, Uljin-gun, Gyeongsangbuk-do & $36^{\circ} 40.606 \mathrm{~N}$ & $129^{\circ} 27.230 \mathrm{E}$ \\
\hline 29 Aug 2010 & ES-37 & Gusan-ri, Giseong-myeon, Uljin-gun, Gyeongsangbuk-do & $36^{\circ} 45.614 \mathrm{~N}$ & $129^{\circ} 28.335 \mathrm{E}$ \\
\hline 29 Aug 2010 & ES-38 & Sanpo-ri, Geunnam-myeon, Uljin-gun, Gyeongsangbuk-do & $36^{\circ} 51.151 \mathrm{~N}$ & $129^{\circ} 25.644 \mathrm{E}$ \\
\hline 29 Aug 2010 & ES-39 & Eumnam-ri, Uljin-eup, Uljin-gun, Gyeongsangbuk-do & $36^{\circ} 59.076 \mathrm{~N}$ & $129^{\circ} 24.630 \mathrm{E}$ \\
\hline 29 Aug 2010 & ES-40 & Jukbyeon-ri, Jukbyeon-myeon, Uljin-gun, Gyeongsangbuk-do & $37^{\circ} 03.487 \mathrm{~N}$ & $129^{\circ} 25.303 \mathrm{E}$ \\
\hline 30 Aug 2010 & ES-41 & Wondeok-eup, Samcheok-si, Gangwon-do & $37^{\circ} 13.782 \mathrm{~N}$ & $129^{\circ} 20.715 \mathrm{E}$ \\
\hline 30 Aug 2010 & ES-42 & Chogok-ri, Geundeok-myeon, Samcheok-si, Gangwon-do & $37^{\circ} 18.584 \mathrm{~N}$ & $129^{\circ} 17.645 \mathrm{E}$ \\
\hline 30 Aug 2010 & ES-43 & Jeongha-dong, Samcheok-si, Gangwon-do & $37^{\circ} 26.315 \mathrm{~N}$ & $129^{\circ} 11.261 \mathrm{E}$ \\
\hline 30 Aug 2010 & ES-44 & Daejin-dong, Donghae-si, Gangwon-do & $37^{\circ} 34.804 \mathrm{~N}$ & $129^{\circ} 06.825 \mathrm{E}$ \\
\hline 26 Feb 2013 & ES-45 & Geumjin-ri, Okgye-myeon, Gangneung-si, Gangwon-do & $37^{\circ} 39.151 \mathrm{~N}$ & $129^{\circ} 03.107 \mathrm{E}$ \\
\hline 21 Apr 2013 & ES-46 & Aninjin-ri, Gangdong-myeon, Gangneung-si, Gangwon-do & $37^{\circ} 44.078 \mathrm{~N}$ & $128^{\circ} 59.224 \mathrm{E}$ \\
\hline 22 Jul 2010 & ES-47 & Sacheonjin-ri, Sacheon-myeon, Gangneung-si, Gangwon-do & $37^{\circ} 50.261 \mathrm{~N}$ & $128^{\circ} 52.605 \mathrm{E}$ \\
\hline 22 Jul 2010 & ES-48 & Susan-ri, Sonyang-myeon, Yangyang-gun, Gangwon-do & $38^{\circ} 04.627 \mathrm{~N}$ & $128^{\circ} 40.431 \mathrm{E}$ \\
\hline $22 \mathrm{Jul} 2010$ & ES-49 & Jucheong-ri, Ganghyeon-myeon, Yangyang-gun, Gangwon-do & $38^{\circ} 07.385 \mathrm{~N}$ & $128^{\circ} 37.942 \mathrm{E}$ \\
\hline $22 \mathrm{Jul} 2010$ & ES-50 & Bongpo-ri, Toseong-myeon, Goseong-gun, Gangwon-do & $38^{\circ} 15.050 \mathrm{~N}$ & $128^{\circ} 34.055 \mathrm{E}$ \\
\hline 22 Jul 2010 & ES-51 & Jugwang-myeon, Goseong-gun, Gangwon-do & $38^{\circ} 19.474 \mathrm{~N}$ & $128^{\circ} 31.598 \mathrm{E}$ \\
\hline $23 \mathrm{Jul} 2010$ & ES-52 & Yangbuk-myeon, Gyeongju-si, Gyeongsangbuk-do & $35^{\circ} 51.805 \mathrm{~N}$ & $128^{\circ} 55.622 \mathrm{E}$ \\
\hline $23 \mathrm{Jul} 2010$ & ES-53 & Jeodong-ri, Ulleung-eup, Ulleung-gun, Gyeongsangbuk-do & $37^{\circ} 29.712 \mathrm{~N}$ & $130^{\circ} 54.471 \mathrm{E}$ \\
\hline
\end{tabular}




\begin{tabular}{|c|c|c|c|c|}
\hline Date & Station & Locality & Latitude & Longitude \\
\hline $23 \mathrm{Jul} 2010$ & $\mathrm{YS}^{2}-01$ & Jeongwang-dong, Siheung-si, Gyeonggi-do & $37^{\circ} 19.572 \mathrm{~N}$ & $126^{\circ} 39.282 \mathrm{E}$ \\
\hline $23 \mathrm{Jul} 2010$ & YS-02 & Jeon-gok-ri, Seosin-myeon, Hwaseong-si, Gyeonggi-do & $37^{\circ} 11.209 \mathrm{~N}$ & $126^{\circ} 39.109 \mathrm{E}$ \\
\hline $23 \mathrm{Jul} 2010$ & YS-03 & Gungpyeong-ri, Seosin-myeon, Hwaseong-si, Gyeonggi-do & $37^{\circ} 06.951 \mathrm{~N}$ & $126^{\circ} 40.618 \mathrm{E}$ \\
\hline $23 \mathrm{Jul} 2010$ & YS-04 & Hanjin-ri, Songak-eup, Dangjin-gun, Chungcheongnam-do & $36^{\circ} 58.248 \mathrm{~N}$ & $126^{\circ} 46.993 \mathrm{E}$ \\
\hline $24 \mathrm{Jul} 2010$ & YS-05 & Hwagok-ri, Daesan-eup, Seosan-si, Chungcheongnam-do & $37^{\circ} 00.185 \mathrm{~N}$ & $126^{\circ} 27.201 \mathrm{E}$ \\
\hline 24 Jul 2010 & YS-06 & Buseok-myeon, Seosan-si, Chungcheongnam-do & $36^{\circ} 37.465 \mathrm{~N}$ & $126^{\circ} 22.003 \mathrm{E}$ \\
\hline $24 \mathrm{Jul} 2010$ & YS-07 & Gung-ri, Seobu-myeon, Hongseong-gun, Chungcheongnam-do & $36^{\circ} 35.572 \mathrm{~N}$ & $126^{\circ} 27.209 \mathrm{E}$ \\
\hline $24 \mathrm{Jul} 2010$ & YS-08 & Dodun-ri, Seo-myeon, Seocheon-gun, Chungcheongnam-do & $36^{\circ} 09.481 \mathrm{~N}$ & $126^{\circ} 30.023 \mathrm{E}$ \\
\hline $24 \mathrm{Jul} 2010$ & YS-09 & Dasa-ri, Biin-myeon, Seocheon-gun, Chungcheongnam-do & $36^{\circ} 05.867 \mathrm{~N}$ & $126^{\circ} 36.869 \mathrm{E}$ \\
\hline 14 Oct 2010 & YS-10 & Sutong-ri, Buri-myeon, Geumsan-gun, Chungcheongnam-do & $35^{\circ} 38.287 \mathrm{~N}$ & $126^{\circ} 27.771 \mathrm{E}$ \\
\hline 15 Oct 2010 & YS-11 & Simpo-ri, Jinbong-myeon, Gimje-si, Jeollabuk-do & $35^{\circ} 51.406 \mathrm{~N}$ & $126^{\circ} 41.940 \mathrm{E}$ \\
\hline 15 Nov 2010 & YS-12 & Byeonsan-myeon, Buan-gun, Jeollabuk-do & $35^{\circ} 56.146 \mathrm{~N}$ & $126^{\circ} 31.672 \mathrm{E}$ \\
\hline 15 Nov 2010 & YS-13 & Okdo-myeon, Gunsan-si, Jeollabuk-do & $35^{\circ} 49.387 \mathrm{~N}$ & $126^{\circ} 28.352 \mathrm{E}$ \\
\hline 15 Nov 2010 & YS-14 & Byeonsan-myeon, Buan-gun, Jeollabuk-do & $35^{\circ} 43.670 \mathrm{~N}$ & $126^{\circ} 31.759 \mathrm{E}$ \\
\hline 16 Nov 2010 & YS-15 & Daehang-ri, Byeonsan-myeon, Buan-gun, Jeollabuk-do & $35^{\circ} 41.283 \mathrm{~N}$ & $126^{\circ} 31.922 \mathrm{E}$ \\
\hline 16 Nov 2010 & YS-16 & Sinsido-ri, Okdo-myeon, Gunsan-si, Jeollabuk-do & $35^{\circ} 43.732 \mathrm{~N}$ & $126^{\circ} 31.916 \mathrm{E}$ \\
\hline 16 Nov 2010 & YS-17 & Wolgot-dong, Siheung-si, Gyeonggi-do & $37^{\circ} 23.247 \mathrm{~N}$ & $126^{\circ} 44.413 \mathrm{E}$ \\
\hline 17 Nov 2010 & YS-18 & Sangrok-gu, Ansan-si, Gyeonggi-do & $35^{\circ} 47.634 \mathrm{~N}$ & $126^{\circ} 38.629 \mathrm{E}$ \\
\hline 09 Jun 2011 & $S S^{3}-01$ & Ogam-dong, Mokpo-si, Jeollanam-do & $34^{\circ} 47.803 \mathrm{~N}$ & $126^{\circ} 26.097 \mathrm{E}$ \\
\hline 09 Jun 2011 & SS-02 & Sani-myeon, Haenam-gun, Jeollanam-do & $34^{\circ} 43.205 \mathrm{~N}$ & $126^{\circ} 23.178 \mathrm{E}$ \\
\hline 09 Jun 2011 & SS-03 & Yulpo-ri, Hoecheon-myeon, Boseong-gun, Jeollanam-do & $34^{\circ} 39.894 \mathrm{~N}$ & $127^{\circ} 04.991 \mathrm{E}$ \\
\hline 30 Aug 2010 & SS-04 & Duwon-myeon, Goheung-gun, Jeollanam-do & $34^{\circ} 42.801 \mathrm{~N}$ & $127^{\circ} 16.017 \mathrm{E}$ \\
\hline 30 Aug 2010 & SS-05 & Gyoryang-dong, Suncheon-si, Jeollanam-do & $34^{\circ} 54.535 \mathrm{~N}$ & $127^{\circ} 30.316 \mathrm{E}$ \\
\hline 30 Aug 2010 & SS-06 & Geumseong-myeon, Hadong-gun, Gyeongsangnam-do & $34^{\circ} 56.406 \mathrm{~N}$ & $127^{\circ} 47.424 \mathrm{E}$ \\
\hline 30 Aug 2010 & SS-07 & Nambu-myeon, Geoje-si, Gyeongsangnam-do & $34^{\circ} 44.157 \mathrm{~N}$ & $128^{\circ} 40.512 \mathrm{E}$ \\
\hline 26 Feb 2013 & SS-08 & Wondong-ri, Gunoe-myeon, Wando-gun, Jeollanam-do & $34^{\circ} 23.575 \mathrm{~N}$ & $126^{\circ} 38.907 \mathrm{E}$ \\
\hline 21 Apr 2013 & SS-09 & Hoejin-ri, Hoejin-myeon, Jangheung-gun, Jeollanam-do & $34^{\circ} 28.843 \mathrm{~N}$ & $126^{\circ} 56.460 \mathrm{E}$ \\
\hline $22 \mathrm{Jul} 2010$ & SS-10 & Yulpo-ri, Hoecheon-myeon, Boseong-gun, Jeollanam-do & $34^{\circ} 40.052 \mathrm{~N}$ & $127^{\circ} 05.815 \mathrm{E}$ \\
\hline 11 Jun 2011 & SS-11 & Noil-ri, Gwayeok-myeon, Goheung-gun, Jeollanam-do & $34^{\circ} 40.893 \mathrm{~N}$ & $127^{\circ} 19.043 \mathrm{E}$ \\
\hline 11 Jun 2011 & SS-12 & Soho-dong, Yeosu-si, Jeollanam-do & $34^{\circ} 44.793 \mathrm{~N}$ & $127^{\circ} 39.501 \mathrm{E}$ \\
\hline 11 Jun 2011 & SS-13 & Nambyeon-ri, Namhae-eup, Namhae-gun, Gyeongsangnam-do & $34^{\circ} 48.658 \mathrm{~N}$ & $127^{\circ} 50.135 \mathrm{E}$ \\
\hline 26 Feb 2013 & SS-14 & Hwagye-ri, Idong-myeon, Namhae-gun, Gyeongsangnam-do & $34^{\circ} 46.528 \mathrm{~N}$ & $127^{\circ} 56.565 \mathrm{E}$ \\
\hline 11 Jun 2011 & SS-15 & Daebang-dong, Sacheon-si, Gyeongsangnam-do & $34^{\circ} 55.978 \mathrm{~N}$ & $128^{\circ} 03.033 \mathrm{E}$ \\
\hline 11 Jun 2011 & SS-16 & Pangok-ri, Samsan-myeon, Goseong-gun, Gyeongsangnam-do & $34^{\circ} 56.423 \mathrm{~N}$ & $128^{\circ} 18.433 \mathrm{E}$ \\
\hline 11 Jun 2011 & SS-17 & Anjeong-ri, Gwangdo-myeon, Tongyeong-si, Gyeongsangnam-do & $34^{\circ} 56.246 \mathrm{~N}$ & $128^{\circ} 25.711 \mathrm{E}$ \\
\hline 26 Feb 2013 & SS-18 & Galgot-ri, Nambu-myeon, Geoje-si, Gyeongsangnam-do & $34^{\circ} 44.145 \mathrm{~N}$ & $128^{\circ} 40.558 \mathrm{E}$ \\
\hline 11 Jun 2011 & SS-19 & Noksan-dong, Gangseo-gu, Busan & $35^{\circ} 01.687 \mathrm{~N}$ & $128^{\circ} 48.856 \mathrm{E}$ \\
\hline 11 Jun 2011 & SS-20 & Dadae-dong, Saha-gu, Busan & $35^{\circ} 02.913 \mathrm{~N}$ & $128^{\circ} 58.260 \mathrm{E}$ \\
\hline 11 Jun 2011 & SS-21 & Suyeong-dong, Suyeong-gu, Busan & $35^{\circ} 09.691 \mathrm{~N}$ & $129^{\circ} 08.297 \mathrm{E}$ \\
\hline
\end{tabular}

${ }^{1} \mathrm{ES}$, East Sea; ${ }^{2}$ YS, Yellow Sea; ${ }^{3} \mathrm{SS}$, South Sea. 